Other theoretical reasons for continuing breast feeding during diarrhoea also need to be considered. Short term deprivation of nutrients by withholding breast feeding during the early acute phase of diarrhoea is serious as a fasting child loses an estimated $1-2^{\circ}$ of his or her body weight daily even in the absence of fluid losses due to diarrhoea. ${ }^{9}$ Breast fed children with diarrhoea have been shown to average a total energy intake $35 \%$ greater and a protein intake $250^{\circ}$ o greater than children who are completely weaned. ${ }^{10}$ Thus breast feeding not only confers protection against infections including diarrhoea and provides a low cost, highly nutritious source of uncontaminated food but also minimises the reduction in energy and protein consumption during diarrhoea and, as found in this study, exerts a beneficial effect on the clinical course and outcome of acute diarrhoea by reducing the number (and volume) of diarrhoeal stools.

We thank Dr Aung Than Batu for his guidance and criticism and $\mathrm{Dr} \mathrm{Ba}$ Tun and the nursing staff of the paediatric wards of the Infectious Diseases Hospital for their help with the project. This project was supported in part by a clinical research grant from the Department of Medical Research.

\section{References}

1 World Health Organisation. Treatment and prevention of dehydration in diarrhoeal

2 World Health Organisation. Clinical management of acute diarrhoea. Diarrhoeal Diseases Control Programme. Report of a scientific working group. Geneva: WHO,

3 Chung AW. The effect of oral feeding at different levels on the absorption of food stuffs in infantile diarrhoea. $\mathcal{F}$ Pediatr $1948 ; 33: 1-13$.

. The early feeding versus early oral starvation on the course of infantile diarrhoea. I Pediatr $1948 ; 33: 14-22$.

Che course of infantile diarrhoca $f$ Pedialr 1948 ;33:14-22. cholera in children. Am f Clin Nutr 1981;34:1548-51.

Braun $\mathrm{OH}$, Sander A. Special milk formulas in the dietary treatment of diarrhoea in infants. Monatsschr Kinderheilkd 1981;129:467-71.

Cleary TG, Cleary KR, DuPont HL, et al. The relationship of oral rehydration solution to hypernatremia in infantile diarrhea. $\mathcal{F}$ Pediatr $1981 ; 99: 739-41$.

Pa SC, Mahalanabis D, Jalan KN, Sen A, Banerjee P. In search of a super olution: controlled trial of glycine-glucose oral rehydration solution in infantile diarrhoea. Acta Paediatr Scand 1984;73:18-21.

9 Rhode JE. Preparing for the next round: convalescent care after acute infection. Am 7 Clin Nutr 1978:31:2258-68.

10 Chen LC, Huq E, Huffman SL. A prospective study of the risk of the diarrhoeal diseases according to nutritional status of children Boston: Harvard University School of Public Health, Department of Population Sciences Report, 1980.

\title{
Effect of long term hormone replacement on plasma prolactin concentrations in women after oophorectomy
}

\author{
D H BARLOW， G H BEASTALL， H I ABDALLA，J ELIAS-JONES， R LINDSAY， D M HART
}

\begin{abstract}
Plasma prolactin concentrations were studied in 88 oophorectomised women who had been receiving mestranol or placebo for three to 11 years. Thirty one of them were also studied under basal conditions and by tests with thyrotrophin releasing hormone. Under basal conditions the mean prolactin concentration was higher in the oestrogen treated group but under nonrested, clinic conditions the difference was lost because of a rise in prolactin value in the placebo group only. Hence the groups showed a different prolactin response to the mild stress of clinic attendance but the same proportionate responsiveness to thyrotrophin releasing hormone.

The data suggest that long term hormone replacement has no significant effect on circulating prolactin concentrations under non-rested, everyday conditions and that the prolactin stimulating effects of minor stress and oestrogen may share a similar mechanism.
\end{abstract}

\section{Introduction}

A large number of women now receive oestrogen preparations on a long term basis. Oestrogen stimulates prolactin release in normal ${ }^{1}$ and hypogonadal women, ${ }^{2}$ probably by both hypothalamic dopamine suppression and direct action on the lactotroph. ${ }^{3}{ }^{4}$ There has been concern whether women receiving oestrogen preparations long term are at increased risk of developing prolactinoma or breast cancer. In relation to prolactinoma current evidence favours no increased risk in users of oral contraceptives, ${ }^{5}{ }^{6}$ though some workers have mooted such a risk. ${ }^{7} 8$

The question of a relation between use of oral contraceptives and breast cancer has been examined recently. ${ }^{9}$ Published work on postmenopausal use of oestrogen and the risk of breast cancer is contradictory, but current data do not suggest a significant increased risk. ${ }^{11}{ }^{11}$ There is a potential for oestrogen treatment to stimulate breast tissue by direct action and by virtue of a chronic increase in circulating prolactin concentrations. The role of prolactin in the induction of breast cancer remains ill defined, ${ }^{12} 13$ but there is evidence that prolactin promotes the development and growth of mammary tumours in rodents. ${ }^{14}$

There is limited information on the effect on plasma prolactin of menopausal oestrogen replacement therapy as used in clinical practice..$^{15} 16$ This study examines the effect of long term, low dose mestranol on plasma prolactin concentrations and responses to thyrotrophin releasing hormone in a large placebo controlled series originally set up to study oestrogen prophylaxis against postoophorectomy oesteoporosis. ${ }^{17}$

\section{Patients and methods}

All patients in the study had undergone hysterectomy and bilateral oophorectomy three months, three years, or six years before entry to the series. Allocation to treatment was randomised and patients took continuous oral mestranol $24 \mu \mathrm{g}$ daily (17-ethinyloestradiol-3- 
methyl ether) or placebo on a double blind basis. Patients gave informed consent to the study, which was approved by the ethical committee. Long term follow up to assess bone density was at yearly intervals. All patients remaining in the osteoporosis study were sampled at their yearly visit. They attended fasting for venous blood sampling without a tourniquet between 0830 and 0930 . Concomitant drug treatment was noted.

The original randomised series consisted of 68 women given mestranol and 66 given placebo. ${ }^{17}$ The duration of treatment at the time of sampling ranged from three to 11 years, and since some patients had stopped treatment in those years the numbers tested were 51 taking mestranol (oestrogen group) and 37 taking placebo (control group). There had been a greater loss of patients from the placebo group. Table I lists the characteristics of the two groups studied.

Seventeen of the mestranol treated patients and 14 controls volunteered for a thyrotrophin releasing hormone test. Table II gives the characteristics of these groups. A baseline blood sample was taken after 30 minutes' recumbency, then $200 \mu \mathrm{g}$ thyrotrophin releasing hormone was given intravenously and subsequent blood samples taken after a further 30 and 60 minutes. Blood was sampled through an indwelling cannula to minimise stress. All blood samples were centrifuged, the plasma being separated and stored frozen until assayed by radioimmunoassay for prolactin, luteinising hormone, and follicle stimulating hormone concentrations.

Prolactin was measured by a specific, sensitive, and precise radioimmunoassay using MRC prolactin preparation 75/504 $(650 \mathrm{mU}$ ampoule) as standard. The detection limit of the assay was $30 \mathrm{mU} / \mathrm{l}$ and mean intra-assay precision $5 \%$ and interassay precision $10 \% .{ }^{18}$

The radioimmunoassay methods for luteinising hormone and follicle stimulating hormone are detailed elsewhere. ${ }^{19}$ Statistical analysis was by $t$ test for paired or unpaired data, as appropriate. Since the data exhibited a skewed distribution logarithmic transformation was employed. This produced a normalisation of the data, and the $t$ tests were performed on the log transformed data.
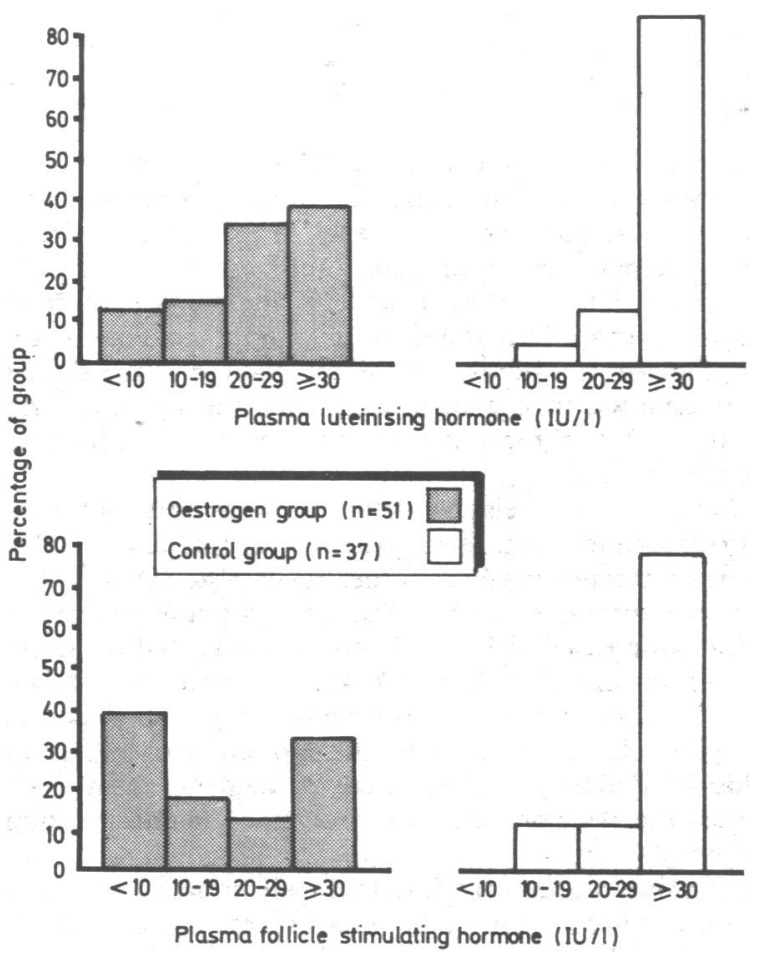

FIG 1-Plasma gonadotrophin concentrations in oestrogen treated and control groups.

\section{Results}

Total population-Figure 1 shows the distribution of plasma follicle stimulating hormone and luteinising hormone concentrations in the two groups. In the oestrogen group 35 patients $(69 \%)$ had a plasma follicle stimulating hormone concentration below $30 \mathrm{IU} / 1$ compared with $8(22 \%)$ of the controls. Similarly, $32(63 \%)$ of the oestrogen group had a plasma luteinising hormone concentration below $30 \mathrm{IU} / 1$ compared with $6(16 \%)$ of the controls. Figure 2 shows the distribution of plasma prolactin concentrations in the two groups, and table III gives the ranges and median and mean values. Mean prolactin concentrations were 242.3 (SD 118.7) $\mathrm{mU} / 1$ in the oestrogen group and $232.6(124.6) \mathrm{mU} / \mathrm{l}$ in the control group. These values were not significantly different.

Thyrotrophin releasing hormone tests-After 30 minutes' rest to achieve a basal state the mean plasma prolactin concentrations were $216 \cdot 1(\mathrm{SD} 140 \cdot 1) \mathrm{mU} / 1$ in the oestrogen group $(n=17)$ and $103 \cdot 6$ $(36.1) \mathrm{mU} / 1$ in the controls $(\mathrm{n}=14)$ (table IV). These values were

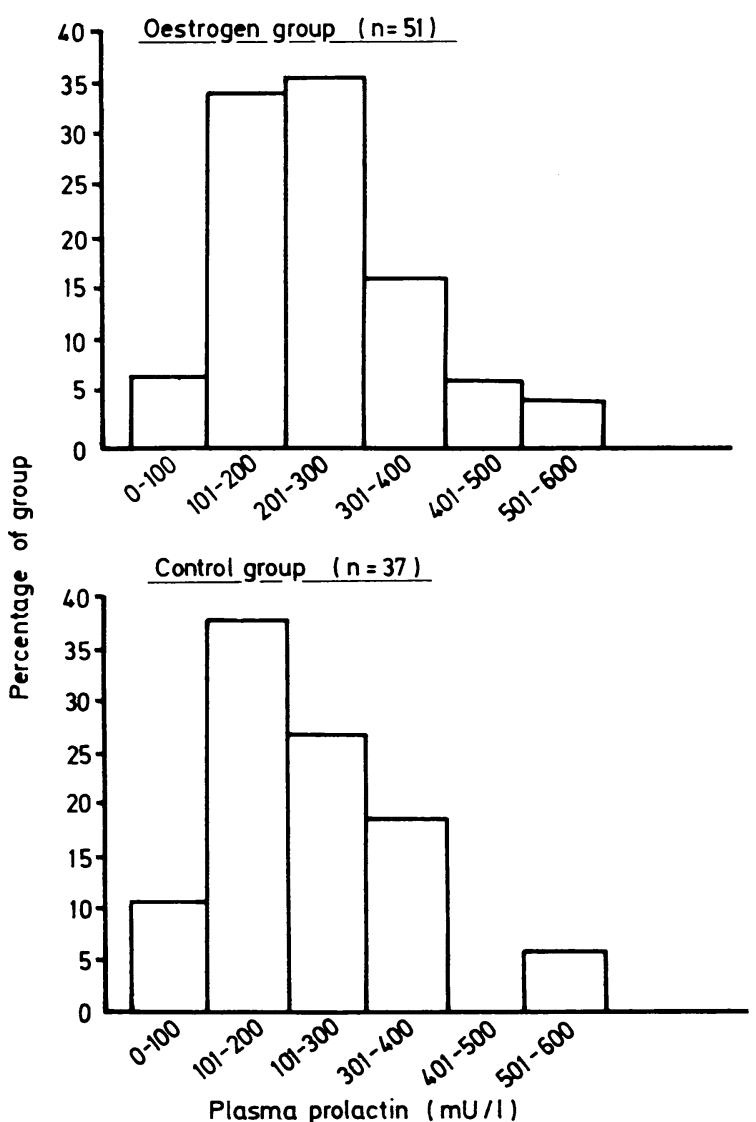

FIG 2-Distribution of plasma prolactin concentrations in oestrogen treated patients and patients taking placebo (control group).

TABLE I-Characteristics of patients in population studied at time of sampling

\begin{tabular}{|c|c|c|c|}
\hline & & $\begin{array}{l}\text { Oestrogen group } \\
\quad(n=51)\end{array}$ & $\begin{array}{c}\text { Control group } \\
(n=37)\end{array}$ \\
\hline Age (years) & $\left\{\begin{array}{l}\text { Mean }(S D) \\
\text { Range }\end{array}\right.$ & $\begin{array}{l}56 \cdot 6(4 \cdot 3) \\
45-64\end{array}$ & $\begin{array}{l}57 \cdot 7(4 \cdot 7) \\
46-66\end{array}$ \\
\hline $\begin{array}{c}\text { Time since hysterectomy } \\
\text { (years) }\end{array}$ & $\left\{\begin{array}{l}\text { Mean }(S D) \\
\text { Range }\end{array}\right.$ & $\begin{array}{c}11 \cdot 3(3 \cdot 5) \\
4-17\end{array}$ & $11 \cdot 4(3 \cdot 7)$ \\
\hline $\begin{array}{l}\text { Duration of treatment at time } \\
\text { of sampling (years) }\end{array}$ & $\left\{\begin{array}{l}\text { Mean }(S D) \\
\text { Range }\end{array}\right.$ & $\begin{array}{l}8 \cdot 1(2 \cdot 4) \\
4-11\end{array}$ & $\begin{array}{l}8 \cdot 5(2 \cdot 4) \\
3-11\end{array}$ \\
\hline $\begin{array}{l}\text { No (\%) who began treatment } \\
\text { at stated times after } \\
\text { hysterectomy }\end{array}$ & $\left\{\begin{array}{l}3 \text { months } \\
3 \text { years } \\
6 \text { years }\end{array}\right.$ & $\begin{array}{r}7(13 \cdot 7) \\
35(68 \cdot 6) \\
9(17 \cdot 6)\end{array}$ & $\begin{array}{r}8(21 \cdot 6) \\
23(62 \cdot 2) \\
6(16 \cdot 2)\end{array}$ \\
\hline $\begin{array}{l}\text { No }(\%) \text { who had been receiving } \\
\text { treatment for the times } \\
\text { stated }\end{array}$ & $\left\{\begin{array}{l}3-5 \text { years } \\
6-8 \text { years } \\
9-11 \text { years }\end{array}\right.$ & $\begin{array}{l}10(19 \cdot 6) \\
14(27 \cdot 5) \\
27(52 \cdot 9)\end{array}$ & $\begin{array}{l}6(16 \cdot 2) \\
10(27 \cdot 0) \\
21(56 \cdot 8)\end{array}$ \\
\hline
\end{tabular}

TABLE II-Characteristics of patients having thyrotrophin releasing hormone tests

\begin{tabular}{|c|c|c|c|}
\hline & & $\begin{array}{c}\text { Oestrogen group } \\
(n=17)\end{array}$ & $\begin{array}{c}\text { Control group } \\
(\mathrm{n}=14)\end{array}$ \\
\hline Age (years) & $\left\{\begin{array}{l}\text { Mean }(S D) \\
\text { Range }\end{array}\right.$ & $\begin{array}{l}58 \cdot 3(4 \cdot 4) \\
47-63\end{array}$ & $\begin{array}{l}58 \cdot 7(4 \cdot 5) \\
48-66\end{array}$ \\
\hline $\begin{array}{l}\text { Time since hysterectomy } \\
\text { (years) }\end{array}$ & $\left\{\begin{array}{l}\text { Mean }(S D) \\
\text { Range }\end{array}\right.$ & $\begin{array}{l}11 \cdot 8(2 \cdot 7) \\
7-14\end{array}$ & $\begin{array}{l}11 \cdot 4(3 \cdot 1) \\
5-15\end{array}$ \\
\hline $\begin{array}{l}\text { Duration of treatment at time } \\
\text { of sampling (years) }\end{array}$ & $\left\{\begin{array}{l}\text { Mean }(\mathrm{SD}) \\
\text { Range }\end{array}\right.$ & $\begin{array}{l}9 \cdot 0(1 \cdot 5) \\
6-11\end{array}$ & $\begin{array}{l}8 \cdot 6(1 \cdot 5) \\
5-11\end{array}$ \\
\hline
\end{tabular}


significantly different $(\mathrm{p}<0.001)$. Comparison of these concentrations with those recorded in the same patients in the larger study showed no difference in the oestrogen group but a significant fall (paired $t$ test $; \mathrm{p}<0.01$ ) in the controls (table IV). Mean prolactin concentration was significantly higher in the oestrogen group at 0,30 , and 60 minutes. The mean prolactin response, taken as the percentage increment over basal value, was not significantly different in the two groups.

TABLE III-Plasma prolactin concentrations $(m U l)$ in total population

\begin{tabular}{lcccc}
\hline & Range & Median & Mean & SD \\
\hline Oestrogen group $(n=51)$ & $77-598$ & 224 & $242 \cdot 3$ & $118 \cdot 7$ \\
Control group $(n=37)$ & $68-548$ & 218 & $232 \cdot 6$ & $124 \cdot 6$ \\
\hline
\end{tabular}

TABLE IV-Results of thyrotrophin releasing hormone (TRH) tests (prolactin $m U / l)$. Values are means ( $S D$ in parentheses)

\begin{tabular}{|c|c|c|c|c|}
\hline & & $\begin{array}{l}\text { Oestrogen } \\
\text { group } \\
(\mathbf{n}=17)\end{array}$ & $\begin{array}{l}\text { Control } \\
\text { group } \\
(\mathrm{n}=1 \mathbf{4})\end{array}$ & $\begin{array}{c}\mathrm{p} \\
\text { value }\end{array}$ \\
\hline \multicolumn{5}{|c|}{ Mean prolactin concentration for } \\
\hline & Basal value & $216.1(140 \cdot 1)$ & $103.6(36 \cdot 1)\rfloor$ & $<0.001$ \\
\hline Result of TRH test & $\{30$ minutes & $1155 \cdot 2(582 \cdot 1)$ & $682 \cdot 1(291 \cdot 4)$ & $<0.02$ \\
\hline \multirow{2}{*}{$\begin{array}{l}\text { Prolactin response to } \\
\text { TRH (" increment } \\
\text { over basal value) }\end{array}$} & & $792 \cdot 8(519 \cdot 7)$ & $415 \cdot 5(178 \cdot 1)$ & \\
\hline & $\left\{\begin{array}{l}30 \text { minutes } \\
60 \text { minutes }\end{array}\right.$ & $\begin{array}{l}536(269) \\
367(240)\end{array}$ & $\begin{array}{l}659(281) \\
401(172)\end{array}$ & $\begin{array}{l}\text { NS } \\
\text { NS }\end{array}$ \\
\hline
\end{tabular}

NS $=$ Not significant.

$+\mathrm{p}<0.01$

\section{Discussion}

The plasma luteinising hormone and follicle stimulating hormone concentrations in the mestranol and placebo treated groups (fig 1) confirm the difference in oestrogenic activity, with a lowering of postoophorectomy gonadotrophin values in the oestrogen group. The gonadotrophin values of some mestranol treated patients remained in the postmenopausal range, but it is well recognised that gonadotrophin responses to oestrogen are variable and that oestrogen does not lower gonadotrophin concentrations into the premenopausal range in all women so treated.

The pattern of plasma prolactin concentrations seen at the clinic and in the rested basal state was different for the two groups of patients. In the rested state, minimising stress effects, the oestrogen treated women had higher mean circulating prolactin values than the control group. In the non-rested state, with the possible influences of minor stress, the difference between the groups was abolished because of a rise in mean prolactin concentration in the controls. There was no change in mean prolactin concentration in the oestrogen group.

Major surgical stress raises the plasma prolactin concentration, ${ }^{20}$ but there are reports that in oestrogen treated women minor stress such as a clinic visit and venepuncture does not alter the concentration, ${ }^{2122}$ and our observations in the mestranol treated group confirm this. There is evidence that in the rested basal state there may be a difference in plasma prolactin concentrations between oestrogenised and non-oestrogenised women, as observed in this study, in that Cowden et al reported a higher mean basal prolactin concentration in women aged 30-50 than in those over $50 .^{18}$

The observations suggest that the effect of minor stress in raising the plasma prolactin concentration may share a common mechanism with the oestrogen mediated effect on prolactin so that the two are not additive in effect in oestrogen treated women. Oestrogens influence neurotransmitter activity but the specific sex steroid-neurotransmitter interactions remain ill defined.

Results of the thyrotrophin releasing hormone tests show that the oestrogenic state of the women did not affect the proportionate lactotroph responsiveness of the two groups to the stimulus, although there was a difference in their response to minor stress.

This study has examined plasma prolactin concentrations in a sizable controlled series of women receiving mestranol at a dosage known to prevent osteoporosis. ${ }^{17}$ An oestrogenic effect on prolactin release in controlled conditions is not disputed, ${ }^{2}$ but the data indicate that in clinical use long term oestrogen replacement has no significant effect on circulating prolactin values, comparing mestranol and placebo in the non-rested state-that is, the state which applies most of the day. In the data of Lind et $a l^{15}$ and Helgason ${ }^{16}$ there was no change in mean prolactin values in smaller treatment groups for up to six months during treatment with "natural" oestrogens. In our study no patient had a prolactin concentration above $600 \mathrm{mU} / 1$. It appears erroneous simply to attribute an abnormally high prolactin concentration to oestrogen replacement therapy, a clinical tendency which we have encountered on several occasions.

If prolactin plays a part in breast cancer it is unlikely to be a mechanism relevant to any relation between breast cancer and oestrogen replacement therapy. Indeed, in our experience of more than 2000 women years of treatment using mestranol or placebo breast cancer occurred in one patient taking mestranol and three receiving placebo; and in the recent report of Gambrell et al on more than 37000 patient years of observation there was a reduction in the risk of breast cancer in postmenopausal women receiving oestrogen replacement therapy.

We are grateful to Searle Pharmaceuticals for supplying the mestranol and placebo tablets, to the staff of the endocrine-metabolic unit, Ruchill Hospital, who performed the thyrotrophin releasing hormone tests, and to Miss D Nolan for clerical work.

\section{References}

1 Vekemans $M$, Robyn $C$. The influence of exogenous estrogen on the circadian periodicity of circulating prolactin in women. $\mathcal{F}$ Clin Endocrinol Metab 1975;

2 Yen SSC, Ehara Y, Siler TM. Augmentation of prolactin secretion by estrogen in hypogonadal women. $\mathcal{f}$ Clin Invest $1974 ; 53: 652-5$.

Meites JK, Lu H, Wuttke W, Welsch CW, Nagasawa H, Quadri SK. Recent studies on functions and control of prolactin secretion in rats. Recent Prog Horm Res $1972 ; 28: 471$

Herbert DC, Hayashida T. Effects of estradiol benzoate on the number of prolactin cells in the primate pituitary. Fourth international congress of endocrinology. Amsterdam: Excerpta Medica, 1972. (Abstract 391.)

Davis JRE, Selby C, Jeffcoate WJ. Oral contraceptive agents do not affect serum prolactin in normal women. Clin Endocrinol (Oxf) 1984;20:427-34.

Jacobs HS, Knuth UA, Huu MGR, Franks S. Post-"pill" amenorrhoeacause or coincidence? $B r$ Med F 1977 ;ii:940-2.

7 Sherman BM, Harris CE, Schlechte J, et al. Pathogenesis of prolactin-secreting pituitary adenomas. Lancet 1978 ;ii:1019-21.

Wingrave SJ, Kay CR, Vessey MP. Oral contraceptives and pituitary adenomas. Br Med F 1980;280:685-6. ine MC, Henderson BE, Krailo MD, Duke A, Roy S. Breast cancer in young women and use of oral contraceptives:

10 Hulka BS, Chambless LE, Deubner DC, Wilkinson WE. Breast cancer and estrogen replacement therapy. Am $\mathcal{F}$ Obstet Gynecol 1982;143:638-44.

11 Gambrell RD, Maier RC, Sanders BI. Decreased incidence of breast cancer in postmenopausal estrogen-progestogen users. Obstet Gynecol 1983;62:435-43.

2 Mack TM, Henderson BE, Gerkws VR, Arthur M, Baptista J, Pike MC. Reserpine and breast cancer in a retirement community. $N$ Engl $\mathcal{f}$ Med 1975;

13 Bullbrook RD. The relationship between changes of prolactin secretion at the menopause and breast cancer. In: van Keep P, Utian WH, Vermeulen A, eds. The controversial climacteric. Lancaster: MTP Press, 1982:55-6.

14 Welsh $\mathrm{CW}$, Nagasawa $\mathrm{H}$. Prolactin and murine mammary tumorigenesis: a review. Cancer Res 1977;37:951-63.
Lind T, Cameron EHD, Hunter WM. Serum prolactin, gonadotrophin and oestrogen levels in women receiving hormone replacement therapy. $\mathrm{Br} \mathcal{F}$ Obstet Gynaecol 1978;85:138-41.

16 Helgason S. Estrogen replacement after the menopause. Biphasic effect on prolactin secretion. Acta Obstet Gynecol Scand 1982;suppl 107:19.

17 Aitken JM, Hart DM, Lindsay R. Oestrogen replacement therapy for prevention of oesteoporosis after oophorectomy. Br Med $\mathcal{J} 1973$;ii:515.

18 Cowden EA, Ratcliffe WA, Beastall GH, Ratcliffe JG. Laboratory assessment of

19 Coutts JRT (ed), Gaukroger JM, Samad Kader A, Macnaughton MC. Steroidogenesis by the human Graafian follicle. In: Functional morphology of the human ovary. Lancaster: MTP Press, 1981:53-72:

20 Noel GL, Suh HK, Stone JG, Frany AG. Human prolactin and growth hormone release during surgery and other conditions of stress. $\mathcal{F}$ Clin Endocrinol Metab

21 Pearce JM, McGarrick G, Chamberlain GVP, Jeffcoate SL. Lack of effect of interview and gynaecological examination on plasma levels of prolactin and cortisol. Brf Obstet Gynaecol 1980;87:366-9.

22 Whittaker PG, Wilcox T, Lind T. The effect of stress upon serum prolactin concentrations in pregnant and non-pregnant women. Fournal of Obstetrics

ccepted 30 November 1984) 